\title{
ASSESSMENT OF TAX BURDEN ON THE OWNERSHIP AND USE OF ROAD PASSENGER TRANSPORT IN RUSSIA
}

\author{
I. MAYBUROV ${ }^{1,2} \&$ Y. LEONTYEVA ${ }^{1}$ \\ ${ }^{1}$ Ural Federal University named after the first President of Russia B.N. Yeltsin, Russia. \\ ${ }^{2}$ Far Eastern Federal University, Russia.
}

\begin{abstract}
The article looks at how taxes influence the tax payers' decision as to whether to own and use commercial passenger vehicles. Types of taxes and fees imposed on the purchase and operation of road passenger transport as a business are described in detail. Substantiation is provided for an idea that it might be useful to introduce a classification that divides taxes into fixed, variable and operation categories with regard to the intensity of commercial passenger vehicle use. The study examines the share of different taxes in the cost of owning and running a commercial passenger vehicle. Calculations are done for the amount of fixed transport taxes per day of owning a vehicle regardless of the intensity of use. A conclusion is made that the total amount of all taxes grows in absolute values for vehicles with a bigger seating capacity, but declines per passenger-kilometer of travel. A conclusion is made that the total amount of all taxes on the use of road passenger transport is much lower than the amount of taxes paid on transporting passengers by car. The goal of this study is to design a method of analyzing the fiscal value of taxes in the cost of owning and operating road passenger transport in Russia.

Keywords: cost of owning, fixed, passenger transport, transport taxation, variable and operating taxes.
\end{abstract}

\section{INTRODUCTION}

Public transport in Russian cities was the main mode of transport until 1990 when car ownership rates started to grow and kept growing further. The low cost of traveling by car discouraged the development of public transit. Only underground networks have retained their competitive edge, having increased their passenger traffic. Other modes of public transit have lost a share of their traffic to privately owned automobiles. The traffic drop is particularly noticeable in cabs, buses and trolleybuses.

This makes it particularly relevant to analyze the costs incurred by those providing passenger transport services by road. It is also important to assess the impact that taxes have on decision-making by transport market participants.

A feature of the present stage of mass car ownership in Russia is that the expansion of road networks is seriously lagging behind growing car and bus fleets. As a result, different modes of transport are competing for access to a limited resource (urban roads). There are no dedicated transit lanes in Russia, so public transport has to compete with automobiles for access to the road network.

Two types of competition are most prominent: (1) competition between privately owned cars and public transport; (2) competition among various modes of public transport (taxi cabs, minibuses for shuttle services, buses of various seating capacity). The purpose of this study is to establish the role that taxes play in decision-making by taxpayers as to whether to own and operate a commercial passenger vehicle in Russia. 


\section{TAXES PAID BY PASSENGER TRANSPORT}

All taxes and levies paid by transport operators should be divided into three groups [1-4].

Fixed taxes. The tax rates are not pegged to the intensity of vehicle use. These are taxes on owning a vehicle. They are paid on a one-time basis when a vehicle is purchased and then on a regular basis regardless of how often the vehicle is used. The size of the taxes is a determining factor of the affordability of a vehicle and, consequently, of the ease of entry into the passenger transport market. The payment of fixed transport taxes is, therefore, viewed as the tax price of owning the vehicle. In Russia, fixed transport taxes include VAT, an excise duty on the purchase of a vehicle, registration fees, the recycling fee and annually paid vehicle tax.

Variable taxes. These taxes depend on the intensity of vehicle use and are taxes on vehicle use. The payment of the taxes is viewed as the price paid for using the road network. In Russia, variable taxes include fuel excise duties.

Taxes on financial results. These are taxes on business activities. They are viewed as the tax price that is paid for running a passenger transportation business. In Russia, taxes on financial results include income tax, the single tax on imputed income and the transport operator license fee. [5].

\section{RESEARCH METHODOLOGY}

The aim of the calculation is to conduct a broad assessment of correspondence between the capacity of the passenger vehicle, the external costs it generates and the costs incurred by the owner of the vehicle. The method used by the authors is simple and it gives only a general idea of the cost of owning the passenger vehicle.

There are methods that allow for making a more detailed assessment of public demand for different modes of transport, ownership costs for transport alternatives (for example rail, sea, and others.) [6-8]. However, they do not solve the problem of analyzing the structure of taxes paid by the owner.

To simplify the calculations we propose using the average passenger load without breaking it down into the seating capacity/total carrying capacity. The calculations factored in the average demand for travel in a large Russian city. A more sophisticated method is required for obtaining refined estimates of the cost of ownership and the share of taxes in the cost.

It is assumed that all types of vehicles generate externalities (negative ones, such as congestion, environmental pollution, road accidents etc., and positive ones, such as improved mobility, territorial integrity of the country etc.).

The evaluation of externalities will be done without quantifying them. We shall proceed from an assumption that negative externalities per passenger are inversely proportional to the number of passengers, while positive externalities per passenger are directly proportional to the number of passengers. Consequently, vehicles that can carry more passengers generate more positive effects and fewer negative effects than vehicles with a smaller seating capacity. This means that the greatest positive effect is produced by vehicles that can carry multiple passengers, while taxi cabs and private cars appear to have the minimum external effect. Consequently, the proposed methodology implies that only explicit costs that are related to owning and operating road transport are accounted for.

To analyze the cost of ownership, three bus models were chosen that make up over $60 \%$ of the bus fleet in Russia (Tables 1 and 2). They are compared to an economy car with a petrol engine (Hyundai Solaris).

The calculations are done for a three-year period of ownership and operation. The vehicles are used for transportation within the city boundaries; the average annual mileage being 
Table 1: Types of buses for calculating ownership costs.

\begin{tabular}{llc}
\hline No & \multicolumn{1}{c}{ Bus type, maker, model } & Share in bus fleet in Russia \\
\hline 1 & GAZ-type (medium bus) PAZ 32053 & 26.1 \\
2 & GAZ-type (city bus) LIAZ 5256 & 16.4 \\
3 & Foreign-made bus (minibus) Ford Transit & 23.6 \\
\hline
\end{tabular}

Table 2: Brief overview of selected vehicles.

\begin{tabular}{|c|c|c|c|c|}
\hline & $\begin{array}{l}\text { Hyundai } \\
\text { Solaris }\end{array}$ & Ford Transit & PAZ 32053 & LIAZ 5256 \\
\hline Engine power, horsepower & 98 & 115 & 125 & 230 \\
\hline $\begin{array}{l}\text { Carrying capacity (seats/ } \\
\text { total) }\end{array}$ & $3 / 3$ & $15 / 15$ & $25 / 42$ & $25 / 110$ \\
\hline Weight, tons & $1.2 / 1.6$ & $1.8 / 2.4$ & $4.9 / 7.7$ & $10.5 / 18.0$ \\
\hline Emission class & Euro 4 & Euro 4 & Euro 3 - Euro 4 & Euro 3 - Euro 4 \\
\hline Price, thousand RUB & 700 & 1,600 & 1,300 & 5,000 \\
\hline $\begin{array}{l}\text { Depreciation (over three } \\
\text { years), } \%\end{array}$ & 23.0 & 37.5 & 30.8 & 30.0 \\
\hline $\begin{array}{l}\text { Fuel consumption, litre / } \\
100 \mathrm{~km}\end{array}$ & 6.8 & 15 & 20 & 32 \\
\hline Fuel & petrol & petrol & diesel & diesel \\
\hline $\begin{array}{l}\text { Average fuel price, RUB / } \\
\text { litre }\end{array}$ & \multicolumn{2}{|c|}{32.50} & \multicolumn{2}{|c|}{35.56} \\
\hline $\begin{array}{l}\text { Annual maintenance costs. } \\
\text { thousand RUB }\end{array}$ & 48 & 52 & 32 & 48 \\
\hline $\begin{array}{l}\text { Insurance premium (yearly), } \\
\text { thousand RUB }\end{array}$ & 65.7 & 38 & 70 & 250 \\
\hline
\end{tabular}

$80,000 \mathrm{~km}$. Other costs are assumed to make up $1 \%$ of the price of a vehicle. The recycling fee is calculated on the basis of the baseline rate of R150000 and adjusted by the bus length coefficient (over $10 \mathrm{~m}-2.36$; less than $10 \mathrm{~m}-1.18$ ).

The choice of taxes on business results is determined by the fact that according to statistics the majority of companies providing transportation services are small businesses and selfemployed individuals (over 95\% of all transport operators). Consequently, the key taxes on financial results are special tax regimes such as the single tax on imputed income (for organizations) and the transport operator license fee (for individuals). 
Table 3: Conditions for calculating taxes on financial results.

\begin{tabular}{|c|c|c|c|}
\hline \multicolumn{2}{|c|}{ Single tax on imputed income } & \multicolumn{2}{|l|}{ Fee for business license } \\
\hline Rate, $\%$ & 15 & Rate, $\%$ & 6 \\
\hline Annual revenue per seat, RUB & 1,500 & Possible annual income & \\
\hline Deflator & 1.798 & $\begin{array}{l}\text { for } 10 \text { vehicles, thousand RUB/ } \\
\text { year }\end{array}$ & 1089.3 \\
\hline Adjustment coefficient & & $\begin{array}{l}\text { per vehicle, thousand RUB/ } \\
\text { year }\end{array}$ & 121 \\
\hline less than 18 seats & 0.8 & $\begin{array}{l}\text { Annual amount of taxes, } \\
\text { thousand RUB }\end{array}$ & \\
\hline over 18 seats & 1 & for 10 vehicles & 65.4 \\
\hline $\begin{array}{l}\text { Annual amount of taxes, thousand } \\
\text { RUB }\end{array}$ & & per vehicle (taxi services) & 7.3 \\
\hline for minibuses with less than 15 seats & 60.7 & & \\
\hline for medium size buses with 25 seats & 80.9 & & \\
\hline for city buses with 25 seats & 80.9 & & \\
\hline
\end{tabular}

Revenues and the amount of taxes to be paid are calculated for organizations and selfemployed individuals that operate 10 buses in a big city (with a population of over 1 million). For the purpose of the calculations we shall assume that providers of passenger transportation services are to pay the single tax on imputed income, while taxi companies are to buy a business license. The main conditions for calculating appropriate tax payments are outlined in Table 3 .

\section{ANALYSIS OF THE COST OF OWNING COMMERCIAL PASSENGER VEHICLES}

The results of calculating the average annual cost of owning and commercially operating a passenger vehicle are shown in Table 4 . The analysis leads to a conclusion that the cost of fuel prevails in the cost of owning a commercial passenger vehicle. For the bus models under consideration, the share of fuel expenses exceeds $50 \%$. The share of mandatory and voluntary insurance tends to go down for vehicles with greater seating capacity. In the case of buses, the share of insurance in total costs does not exceed $9 \%$. The share of maintenance costs tends to fall even further for vehicles with a greater seating capacity: from $13.5 \%$ for a taxi cab to $2.7 \%$ for a full-size bus. Depreciation varies inversely to the size of the vehicles. The share of depreciation in the cost of ownership grows from $11.9 \%$ for a taxi cab to $28.5 \%$ for a large bus. Other expenses, such as the cost of buying winter tires and other expendables needed for the day-to-day operation of a vehicle are insignificant and do not exceed $3 \%$ of the total ownership costs. 
Table 4: Cost of owning and commercially operating a vehicle, thousand RUB/ year.

\begin{tabular}{|c|c|c|c|c|c|}
\hline No & Indicator & $\begin{array}{l}\text { Hyundai } \\
\text { Solaris }\end{array}$ & $\begin{array}{l}\text { Ford } \\
\text { Transit }\end{array}$ & $\begin{array}{c}\text { PAZ } \\
32053\end{array}$ & $\begin{array}{l}\text { LIAZ } \\
5256\end{array}$ \\
\hline \multirow[t]{5}{*}{1} & Depreciation & 42.3 & 200 & 133 & 500 \\
\hline & Recycling fee included & 3.4 & 22 & 18 & 44 \\
\hline & $V A T$ & 5.9 & 30 & 20 & 76 \\
\hline & registration fee & 1 & 1 & 1 & 1 \\
\hline & sales tax & 0.3 & 0 & 0 & 0 \\
\hline \multirow[t]{2}{*}{2} & Fuel & 182 & 390 & 569 & 910 \\
\hline & excise duty included & 23.2 & 50 & 44 & 70 \\
\hline 3 & Mandatory and voluntary insurance & 65.7 & 38 & 70 & 150 \\
\hline \multirow[t]{2}{*}{4} & Taxes, duties and other levies & 1.3 & 4 & 4 & 15 \\
\hline & vehicle tax included & 1.3 & 4 & 4 & 15 \\
\hline 5 & Maintenance & 48 & 52 & 32 & 48 \\
\hline \multirow[t]{2}{*}{6} & Other expenses & 9 & 16 & 13 & 50 \\
\hline & $\begin{array}{l}\text { TOTAL EXPENSES (excluding } \\
\text { taxes on financial results) }\end{array}$ & 348.3 & 700 & 821 & 1,673 \\
\hline \multirow[t]{6}{*}{7} & $\begin{array}{l}\text { Taxes on financial results of passen- } \\
\text { ger transportation business }\end{array}$ & 7.3 & 60.7 & 80.9 & 80.9 \\
\hline & $\begin{array}{l}\text { Total expenses related to owning and } \\
\text { commercially operating a vehicle }\end{array}$ & 355.6 & 760.7 & 901.9 & 1753.9 \\
\hline & including taxes and levies & 42.4 & 167.7 & 167.9 & 286.9 \\
\hline & fixed taxes & 11.9 & 57 & 43 & 136 \\
\hline & variable taxes & 23.2 & 50 & 44 & 70 \\
\hline & on financial results & 7.3 & 60.7 & 80.9 & 80.9 \\
\hline 8 & Cost per km, RUB/km & 4.45 & 9.51 & 11.27 & 21.9 \\
\hline 9 & $\begin{array}{l}\text { Per passenger-kilometer cost, RUB/ } \\
\text { thousand passenger-km* }\end{array}$ & 0.636 & 0.146 & 0.133 & 0.128 \\
\hline
\end{tabular}

Note. * The indicator is calculated on the basis of the number of passengers per vehicle per year: for a taxi cab - 7000 persons/year; a minibus - 65000/ year; a medium-size bus 85000 persons/ year; city bus - 170000 persons/year. 
Table 5: Taxes in vehicle ownership costs (\%).

\begin{tabular}{|c|c|c|c|c|}
\hline Indicator & $\begin{array}{l}\text { Hyundai } \\
\text { Solaris }\end{array}$ & $\begin{array}{l}\text { Ford } \\
\text { Transit }\end{array}$ & $\begin{array}{c}\text { PAZ } \\
32053\end{array}$ & $\begin{array}{l}\text { LIAZ } \\
5256\end{array}$ \\
\hline $\begin{array}{l}\text { Total costs of owning and commercially } \\
\text { operating a passenger vehicle }\end{array}$ & 100 & 100 & 100 & 100 \\
\hline including taxes and other levies & 11.9 & 22.0 & 18.6 & 16.4 \\
\hline fixed & 3.3 & 7.5 & 4.8 & 7.8 \\
\hline variable & 6.5 & 6.6 & 4.9 & 4.0 \\
\hline on financial results & 2.1 & 8.0 & 9.0 & 4.6 \\
\hline
\end{tabular}

\section{ANALYSIS OF TAX BURDEN ON THE OWNERSHIP AND COMMERCIAL OPERATION OF PASSENGER VEHICLES}

The structure of various taxes in the cost of owning and commercially operating passenger vehicles is shown in Table 5.

The analysis indicates that the tax burden on owning a passenger vehicle is higher for vehicles with a bigger seating capacity. The share of fixed taxes in the cost of ownership grows from $3.3 \%$ for taxi cabs to $7.8 \%$ for full-size city buses. The share of taxes on financial results is also higher in the case of roomier vehicles: $2.1 \%$ for taxi cabs operating under the business license regime vs. $9 \%$ in the case of buses that are eligible for the single tax on imputed income. On the opposite, the share of variable taxes goes down from $6.5 \%$ for tax cabs to $4 \%$ for full-size buses.

It has to be noted that the tax burden on owning and commercially operating passenger vehicles is up to $9 \%$ heavier than the tax burden on owning and using a private automobile. The difference is due to taxes on financial results. The structure of fixed and variable taxes for commercial and private passenger vehicles is pretty much identical.

Such a tax burden is against the logic of promoting the development of public transit. The logic of such development stipulates that the tax burden on public transport should be considerably lighter than on private automobiles. Fixed taxes on public transport need to be reduced.

Reducing the fiscal impact of fixed taxes will make public transit more attractive as an alternative to private cars, thus encouraging its development.

\section{CONCLUSION}

The system of transport taxes in Russia needs to be improved. A comprehensive approach is needed that would take into account the balance between the tax burden on various means of transport. The tax burden on private cars should be far heavier than that on public transport. At present, the tax burden on public transport distorts people's preferences in favour of private automobiles. This approach adds to the stagnation of the public transit sector.

\section{REFERENCES}

[1] De Borger, B. \& Mayeres, I., Optimal taxation of car ownership, car use and public transport: insights derived from a discrete choice numerical optimization model. European Economic Review, 51, pp. 1177-1204, 2007. http://dx.doi.org/10.1016/j.euroecorev.2006.08.004 
[2] Litman, T., Transportation Cost and Benefit Analysis: Techniques, Estimates and Implications. Executive Summary, 2nd edn., Victoria Transport Policy Institute, Victoria, p. 238, 2009.

[3] Walker, J., The Acceptability of Road Pricing, Royal Automobile Club Foundation, p. 134, 2011.

[4] Coase, R., The problem of social cost. Journal of Law and Economics. 3(1), pp. 1-44, 1960.

http://dx.doi.org/10.1086/466560

[5] Mayburov, I. \& Leontyeva, Y., Reducing the negative impact of motor transport on the environment: prospects for the use of fiscal instruments in Russia. Proceeding of the Conference Air Pollution 2014, eds. C.A. Brebbia, WIT Transactions on Ecology and the Environment, WIT Press, UK, 186, pp. 863-874, 2014.

http://dx.doi.org/10.2495/esus140771

[6] Abramovic, B., Analysis of the mobility of railway passenger transport in small urban areas. Proceeding of the Conference Urban Transport XXI 2015, eds. C.A. Brebbia, WIT Transactions on the Built of Environment, WIT Press, UK, 164, pp. 665-675, 2015.

http://dx.doi.org/10.2495/ut150541

[7] Russo, F., Rindone, C., D`Agostino, P., Lanciano, C. \& Scattarreggia, T., A city logistic system for long distance freight transport provisioning. Proceeding of the Conference Urban Transport XXI 2015, eds. C.A. Brebbia, WIT Transactions on the Built of Environment, WIT Press, UK, 146, pp. 279-291, 2015.

http://dx.doi.org/10.2495/ut150221

[8] De Maio, M.L. \& Vitetta, A., Route choice on road transport system: a fuzzy approach. Journal of Intelligent and Fuzzy System, 28(5), pp. 2015-2027, 2015. http://dx.doi.org/10.3233/IFS-141375 